\title{
Constraint Analysis of Goat Farmers in Tamil Nadu, India
}

\author{
R. Ravikumar and P. Kumaravel* \\ Department of Veterinary and Animal Husbandry Extension Education, Madras Veterinary \\ College, Vepery, Chennai - 600 007, Tamil Nadu, India \\ *Corresponding author
}

\begin{tabular}{|c|c|}
\hline & A B S T R A C T \\
\hline Keywords & \multirow{7}{*}{$\begin{array}{l}\text { The present study was conducted to delineate the various constraints faced by the goat } \\
\text { farmers in goat rearing in Tiruchirappalli and Salem districts of Tamil Nadu. A sample size } \\
\text { of } 120 \text { goat farmers ( } 60 \text { goat farmers from each district) who were actively involved in } \\
\text { goat rearing were randomly selected for the study. A well-structured, pre-tested interview } \\
\text { schedule was employed for the data collection for the study. The constraints were rated } \\
\text { according to their seriousness as most serious constraint, serious constraint, less serious } \\
\text { constraint and not a constraint by the respondents. Rank based quotient (RBQ) technique } \\
\text { was employed in the present study. The analyzed data revealed that exploitation by } \\
\text { middlemen, poor price paid to the produce, limited drinking water availability, lack of } \\
\text { subsidies and non-availability of grazing land were the most serious constraints faced by } \\
\text { the goat farmers in goat rearing. The suggestions offered to overcome the constraints } \\
\text { encountered were formation of goat farmers association, eradication of middlemen and } \\
\text { providing fodder with subsidies to the needy farmers. }\end{array}$} \\
\hline $\begin{array}{l}\text { Constraints, Goat } \\
\text { farming, }\end{array}$ & \\
\hline Middlemen, & \\
\hline Farmers, & \\
\hline & \\
\hline Article Info & \\
\hline $\begin{array}{l}\text { Accepted: } \\
\text { 04 July } 2017 \\
\text { Available Online: } \\
\text { 10 September } 2017\end{array}$ & \\
\hline
\end{tabular}

\section{Introduction}

Goats play a significant role in the economy and nutrition of landless, small and marginal farmers in India. Around 80 per cent of global goat population is found in developing countries. Among them, India has the second largest population of goats ( 135.17 million) in the world. In a country, where human population is very high and the land available for farming is less, goat farming is the suitable option for small farmers. Goat rearing is an enterprise which has been practiced by a large section of population in rural areas. Goat rearing has considerable potential as a sustainable income generating activity for the rural women as the management of goats is less expensive and requires less labour.
Goats can efficiently survive on available shrubs and trees in adverse harsh environment in low fertile lands where no other crops can be grown. In pastoral and agricultural subsistence societies in India, goats are kept as a source of additional income and as an insurance against disasters. Because of these characteristics, goat farming is carried out as a traditional business by majority of small and marginal farmers in India. Farmers face various hurdles in rearing goats which varies from production to marketing constraints. Production constraints include the managemental, socio-economical, infra structural and technological constraints. With regard to marketing of goats and chevon, the 
farmers are being exploited by middlemen and the margin of profit obtained is comparatively low. Hence, to study the problems faced by the goat farmers, this research work was taken up with the objective to delineate the various constraints faced by the farmers.

\section{Materials and Methods}

Tiruchirappalli and Salem districts of Tamil Nadu state were purposively selected for this study (based on $19^{\text {th }}$ Livestock census of Tamil Nadu) owing to the presence of high goat population in Tamil Nadu. Thuraiyur and Thalaivasal blocks were selected purposively from Tiruchirappalli and Salem districts respectively as it contains the highest number of goat population. The blocks were selected based on the blockwise goat population data of the district available at the office of the Joint Director of Animal Husbandry of these two districts. Keerambur and Naduvalur village panchayats located in Thuraiyur block of Tiruchirappalli district and Navakkurichi and Kattukottai village panchayats located in Thalaivasal block of Salem district were selected for the study. The village panchayats were selected randomly after consulting the local Veterinary Assistant Surgeons about the presence of large number of goat population and the involvement of middlemen in marketing of goats in these selected villages. Thirty goat farmers were drawn from each of the selected villages by random sampling technique, thus making the sample size of 120 from the study area. The data was collected by using a pre-tested interview schedule. The identified constraints were measured on a four point continuum viz. most serious constraint, serious constraint, less serious constraint and not a constraint respectively. Data on perceived constraints were subjected to Rank Based Quotient technique (RBQ) developed by Sabarathnam (2002). For this, ranks were given to most serious constraint, serious constraint, less serious constraint and not a constraint as one, two, three and four respectively. The frequencies of ranks given by the farmers for each of the 36 constraints were calculated and substituted in the below mentioned formula and Rank based Quotient (RBQ) was obtained. The constraints were then ranked in ascending order of the descending order of RBQ of various constraints under each category.

Rank
$\sum_{i=1}^{n}=\frac{\text { based quotient }}{N n} \times 100$

(RBQ),

Where,

$\mathrm{Fi}=$ Frequency of farmers for the $\mathrm{i}^{\text {th }}$ rank of the problem

$\mathrm{n}=$ Total number of ranks

$\mathrm{i}=$ Rank given by the respondents

$\mathrm{N}=$ Total number of respondents contacted

\section{Results and Discussion}

The constraints faced by the goat farmers' namely managemental, socio-economical, infrastructural, technological and marketing constraints are discussed below.

\section{Managemental constraints}

Among the managemental constraints, limited drinking water availability was ranked as the top most serious constraint by $93.3 \%$ of the goat farmers. This was due to the failure of monsoon in Tiruchirappalli and Salem districts for the past three years. The next constraint expressed by the farmers was nonavailability of grazing land and there was less pasture available for the goats to browse and the farmers were forced to purchase concentrates and feed ingredients for their goats during summer which was expensive. 
Majority of the goat farmers who were landless labourers and marginal farmers were forced to sell their goats due to the lack of availability of feed $(87.9 \%)$ and water. There were occasional outbreak of diseases like Peste des petits ruminants (PPR) and Goat pox which was also a constraint faced by $68.5 \%$ of the goat farmers. As majority of the goat farmers had medium herd size and managed on their own, they did not hire any labourers for the management of their goats and this was the fifth and less serious constraint encountered by the goat farmers. These findings are in line with the findings of Gopala et al., (2010) (Table 1).

\section{Socio-economic constraints}

It is clearly evident from table 2 that farmers opined that the cost of medicines and treatment were high and it was ranked as the top most serious constraint by $69.1 \%$ of them among socio-economic constraints. The next constraint faced was theft of goats and kids and nuisance of attacks by dogs.

The farmers requested the government to take adequate measures to control the stray dogs. Though majority of the farmers rear goats, $54.7 \%$ of the farmers felt that they didn't receive any recognition or appreciation from the government or any other institutions and they ranked it as the third most serious constraint. Majority of the landless labourers and marginal farmers (40.4\%) involved in goat rearing did not have enough land for farm expansion which was ranked as the fourth most serious constraint. High cost of feed $(36.4 \%)$, high cost of parent stock (35.6\%), high cost of farm labour $(30.4 \%)$ and high cost of equipments $(25.8 \%)$ were the other socio-economic constraints expressed by the farmers in the order of seriousness. The findings are in accordance with the findings reported by Rajkumar et al., (2014) and Tanwar (2011).

\section{Infrastructural constraints}

Among the Infrastructural constraints, lack of subsidies and inadequate loan facilities were ranked as the top two serious constraints by $90.8 \%$ and $73.5 \%$ of goat farmers respectively. Goat farmers reported that whenever they approach a bank for loan to start a new goat farm or expand an existing goat farm, they were denied.

Lack of institutional support was ranked as the third most serious constraint among infrastructural constraints faced by $73.5 \%$ of the goat farmers. Lack of extension personnel $(57.7 \%)$, difficulty in getting inputs $(46.5 \%)$ and lack of equipments $(25.6 \%)$ were the other infrastructural constraints expressed by the farmers in the order of seriousness. The findings are in line with the findings of Kumar (2007) (Table 3).

Table.1 Managemental constraints faced by the goat farmers in Tiruchirappalli and Salem districts of Tamil Nadu - Rank based quotient method

\begin{tabular}{|c|l|c|c|}
\hline I & Managemental constraints & RBQ value & Rank \\
\hline 1 & Limited drinking water availability & 93.3 & I \\
\hline 2 & Non availability of grazing land & 87.9 & II \\
\hline 3 & Disease outbreak & 68.5 & III \\
\hline 4 & Lack of veterinary aid & 37.9 & IV \\
\hline 5 & Labour shortage & 27.5 & V \\
\hline
\end{tabular}


Table. 2 Socio-economic constraints faced by the goat farmers in Tiruchirappalli and Salem districts of Tamil Nadu - Rank based quotient method

\begin{tabular}{|c|l|c|c|}
\hline II & Socio-economic constraints & RBQ value & Rank \\
\hline 1 & High cost of medicines / treatment & 69.1 & I \\
\hline 2 & Theft/Predators & 65.4 & II \\
\hline 3 & Lack of recognition & 54.7 & III \\
\hline 4 & Limited land for farm expansion & 40.4 & IV \\
\hline 5 & High cost of feed & 36.4 & V \\
\hline 6 & High cost of parent stock & 35.6 & VI \\
\hline 7 & High cost of farm labour & 30.4 & VII \\
\hline 8 & High cost of equipments & 25.8 & VIII \\
\hline
\end{tabular}

Table.3 Infrastructural constraints faced by the goat farmers in Tiruchirappalli and Salem districts of Tamil Nadu - Rank based quotient method

\begin{tabular}{|c|l|c|c|}
\hline III & Infrastructural constraints & RBQ value & Rank \\
\hline 1 & Lack of subsidies & 90.8 & I \\
\hline 2 & Inadequate loan facilities & 73.5 & II \\
\hline 3 & Lack of institutional support & 73.5 & II \\
\hline 4 & Lack of extension personnel & 57.7 & IV \\
\hline 5 & Difficulty in getting inputs & 46.5 & V \\
\hline 6 & Lack of equipments & 25.6 & VI \\
\hline
\end{tabular}

Table.4 Technological constraints faced by the goat farmers in Tiruchirappalli and Salem districts of Tamil Nadu - Rank based quotient method

\begin{tabular}{|c|l|c|c|}
\hline IV & Technological constraints & RBQ value & Rank \\
\hline 1 & Lack of technical support at doorsteps & 75.8 & I \\
\hline 2 & Lack of scientific knowledge & 72.1 & II \\
\hline 3 & Limited training programmes on goat rearing & 42.5 & III \\
\hline 4 & Non-availability of improved breed & 37.5 & IV \\
\hline 5 & Poor veterinary care & 27.5 & V \\
\hline
\end{tabular}

Table.5 Marketing constraints faced by the goat farmers in Tiruchirappalli and Salem districts of Tamil Nadu - Rank based quotient method

\begin{tabular}{|c|l|c|c|}
\hline S. No & \multicolumn{1}{|c|}{ Marketing constraints } & RBQ value & Rank \\
\hline 1 & Middlemen exploitation & 96 & I \\
\hline 2 & Poor price paid to the produce & 93.5 & II \\
\hline 3 & Absence of price fixing agency & 89.6 & III \\
\hline 4 & No organized/authorized agents & 87.7 & IV \\
\hline 5 & Unscientific price fixation & 86.4 & V \\
\hline 6 & Lack of marketing information & 81.2 & VI \\
\hline 7 & Non availability of markets & 79.5 & VII \\
\hline 8 & Long distance to market & 75.8 & VIII \\
\hline 9 & Poor infrastructure facilities at shandy & 72.5 & IX \\
\hline 10 & Inadequate transport facility & 48.3 & X \\
\hline 11 & Season & 47.9 & XI \\
\hline 12 & Limited labs for quality control for export & 25.8 & XII \\
\hline
\end{tabular}




\section{Technological constraints}

Among the technological constraints, majority of the farmers were involved in agriculture work along with goat farming and they could not find time to approach any extension agency which was located quite far from their residential area. Hence nearly $75.8 \%$ of farmers expected technical support at doorsteps from the Government and Nongovernment extension agencies. About $72.1 \%$ of farmers expressed that they lack scientific knowledge in rearing goats and were eager to learn improved methods of goat rearing and about $42.5 \%$ of farmers opined that there is limited conduct of training programmes and expressed that there should be more farmer specific training programmes based on the number of animals and the method of marketing. Non-availability of improved breed $(37.5 \%)$ and poor veterinary care $(27.5 \%)$ were ranked as the fourth and fifth constraint by the goat farmers (Table 4).

\section{Marketing constraints}

Exploitation by middlemen was ranked as the top most serious constraint by $96 \%$ of the goat farmers as they shared most of the profit. The price paid to the produce by the middlemen was very less and $93.5 \%$ of farmers ranked it as the second most serious constraint. There was no single organized price fixing agency and availability of authorized agents for fixing the price of goats which was ranked as third and fourth constraint by $89.6 \%$ and $87.7 \%$ of farmers. Unscientific price fixation (86.4\%) was ranked as the fifth most serious constraint as there was no proper procedure of weighing the goats and fixing the price by the traders and butchers. The price of goats was fixed based on the thickness of the thigh and lumbar vertebrae or by lifting the hind limbs and arbitrarily measuring the weight. Lack of marketing information (81.2\%), non- availability of markets (79.5\%), long distance to market $(75.8 \%)$, poor infrastructure facilities at shandy $(72.5 \%)$, inadequate transport facility (48.3\%), season (47.9\%) and limited labs for quality control for export (25.8\%) were the other constraints ranked in the order of seriousness. The findings are in line with the findings of Rajkumar et al., (2014), Kumar (2007), Tanwar (2011) and Nepali et al., (2007) (Table 5).

Suggestions for the amelioration of the livelihood by eradicating the perceived constraints of the goat farmers

It was observed from the present study that majority of goat farmers in Tiruchirappalli and Salem districts of Tamil Nadu state had serious constraints pertaining to exploitation by middlemen, absence of a price fixing agency, non-availability of water and fodder during summer season, lack of subsidies and technical support at doorsteps.

Based on the findings of the study it is concluded that the goat farmers of the villages must be organised into groups and they should be imparted capacity building training programmes by government and nongovernment extension agencies. Rain water harvesting measures may be taken not only in the study area but also in other areas of Tamil Nadu which experience more rainfall during monsoon, so that water can be supplied from those areas to water deficient areas. Subsidized fodder for goats can be provided during summer season as majority of the farmers sell their goats for less price due to non-availability of feed and water.

Formation of commodity interest groups (CIG's) on goat has more advantages as the farmers can approach any bank for loan to start/expand a goat farm or in creating a link between the farmers and big traders/meat exporters bypassing the middlemen and in 
turn obtain huge profit. A goat co-operative society similar to milk co-operative society should be set up for price fixation of goats for effective marketing.

\section{References}

Anonymous, 2012. Statistics, B. A. H. 19th Livestock census. Department of Animal Husbandry, Dairying and Fisheries, Ministry of Agriculture, Government of India.

Gopala, G.T., K.C. Veeranna, and S.K. Radder, 2010. Constraints in goat farming in Bidar district of Karnataka state. Research Journal of Animal Husbandry and Dairy Science, 1(2): 8082.

Kumar, S., 2007. Commercial goat farming in India: An emerging agri-business opportunity. Agricultural Economics
Research Review, 20: pp 503-520.

Nepali, M.B., M.R. Tiwari, S. Sapkota, H.P. Poudel, B.R. Acharya and S. Gautam, 2007. Marketing constraints to goats in the western hill of Nepal. Nepal Agric. Res. J. Vol. 8: 95-102.

Rajkumar, N.V., and N.V. Kavithaa, 2014. Constraints in goat farming perceived by farm women in erode district of Tamilnadu. Internat. J. Sci. Environ. Technol, 3(1), 116-122.

Sabarathnam, V.E., 2002. RRA/PRA for Agriculture, Vamsaravath Publisher, 512-210, Hyderabad-500 040: pp354355.

Tanwar, P.S., 2011. Constraints perceived by goat keepers in adoption of goat husbandry practices in semi-arid Rajasthan. Journal of Community Mobilization and Sustainable Development, 6(1): 108-111.

\section{How to cite this article:}

Ravikumar, R. and Kumaravel, P. 2017. Constraint Analysis of Goat Farmers in Tamil Nadu, India. Int.J.Curr.Microbiol.App.Sci. 6(9): 594-599.

doi: https://doi.org/10.20546/ijcmas.2017.609.072 